\title{
鉄芽球性貧血様のrefractory anemiaを伴つた
} 本態性成人型Fanconi症候群の 1 例

\author{
東京都眼育院付属病院内科 \\ 村井 善郎〉 池淵 研二 深山 牧子 \\ 三輪 哲義 白木 正孝 森 真由美 \\ 群馬大学医学部付属病院草津分院 \\ 白倉 卓夫
}

\section{A CASE OF PRIMARY ADULT FANCONI SYNDROME WITH REFRACTORY ANEMIA CLOSELY RELATED TO SIDEROBLASTIC ANEMIA}

Yoshiro Murai, MD, Kenji Ikebuchi, MD, Makiko FuKayama, MD

Akiyoshi Mrwa, MD, Masataka SIRAKI, MD and Mayumi MORI, MD

Department of Internal Medicine, Tokyo Metropolitan Geriatric Hospital Takuo SHIRAKURA, MD

Department of Internal Medicine, Kusatsu Branchi Hospital, University of Gumma

概要 Fanconi症候群にsideroblastic anemia様のrefractory anemiaを合併した症例孝報告 し，考察を加光た。症例は92才，女性。Cd污染地区での居住歴なし，1972年動悸，息切れ，貧 血，腰痛があつた。1976年11月負血の精査のため当院入院、肝脾腫なし，入院時検查所見で代 謝性アンドーシスを認めた。 $\mathrm{NH}_{4} \mathrm{Cl}$ 負荷試駼で尿酸性化能の障害があり，遠位尿細管障害の存

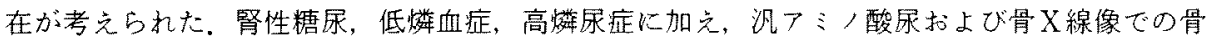

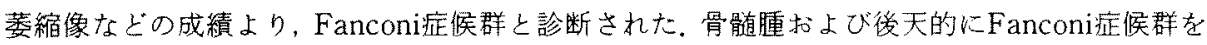
来すとされる要因は認めなかつた，活性型ビタミンDに反応し，腰痛，腎性栲尿，低燐血症の 改善を認めたが，1981年 4 月5つ血性心不全に血管内凝固症候群を併発し死亡した。剖唡では 両側腎とも著明に萎縮し, 組織学的には細動脈硬化像に上るnephronの荒廃に加兄, 間質性腎炎 像を強く認めた。骨は典型的ではないが，osteoporo-malaticな変化があつた。本症例は低色素 性，小球性貧血を合併していた，骨㖪では赤芽球過形成（環状担鉄芽球(一)）に加えて，無効 造血の存在, 骨䯣赤芽球 $\delta$ ALA合成酵素低值, 一モグロビン異常を認めるなどの成績より, refractory anemiaと診断された. Fanconi症候群と, refractory anemiaが合併したことは，両 疾患の悪性腫瘍との関係を考慮すると，両者の病態を検討する際，示唆にとむ点と思われた。

\section{I. 緒 言}

種々の原因で近位尿細管に㧍ける再吸取障害が 扣こり，アミ，酸尿，リン酸尿，糖尿を呈し，く

[昭和58年 7 月11日受稿]
る病，骨軟化症や発育障害をきたすFanconi症候 群（以下FC症候群と略）徒，1924年Lignac ${ }^{11}$ によ り第 1 例が報告された。その後Fanconi'23)，de

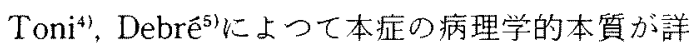
細に検討されたため,本症候群はde Toni-Debré- 
Fanconi症候群と別称されている。

成人型 $\mathrm{FC}$ 症候群は1930年Milkman ${ }^{6}$ に上り初 めて報告され，その後多くの報告があるが，骨䯣 腫などの二次性 $\mathrm{FC}$ 症候群を除いた特発性FC症候 群はまれな疾患上されている。我々はいわゆる特 発性成人型FC症候群にrefractory anemiaを合併 した興味ある1剖検例を経験したので報告する。

\section{II. 症例}

患者 92 才, 主婦.

主訴: 全身供念感, 息切れ, 腰痛。

家族歴：特になし。

既往歴：特になし、Tetracyclineを投与され たことはなく、鉛，カドミウムに污染された地域 に居住したこともない

現病歴：1972年以前, 糖疗病之指摘されたこ とがあつたが, 精査の結果, 異常なしと言われた。 1972年動悸，息切れ出現，歩行不能となり，奢血 症と診断され某院入院, 計約 $1400 \mathrm{ml}$ の輸血を受け た。退院後腰痛が出現した。1974年11月養育院入 寮。入寮時健診で代謝性アシドーシスが認められ た．1975年6月負血が進行したため鉄郕を投与さ れたが，改善せず，1000 $\mathrm{ml}$ 輸血を受けたのち， 1975年11月当院に入院した。
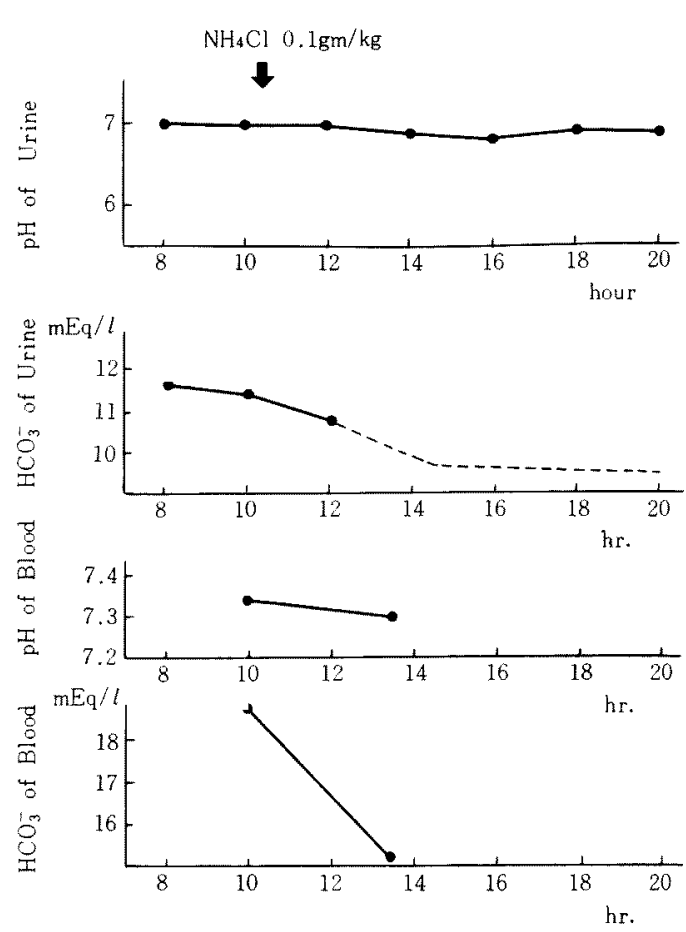

图 1. Ammonium chloride loading test (method of Wrong \& Davis)

表 1. Laboratory findings on admission

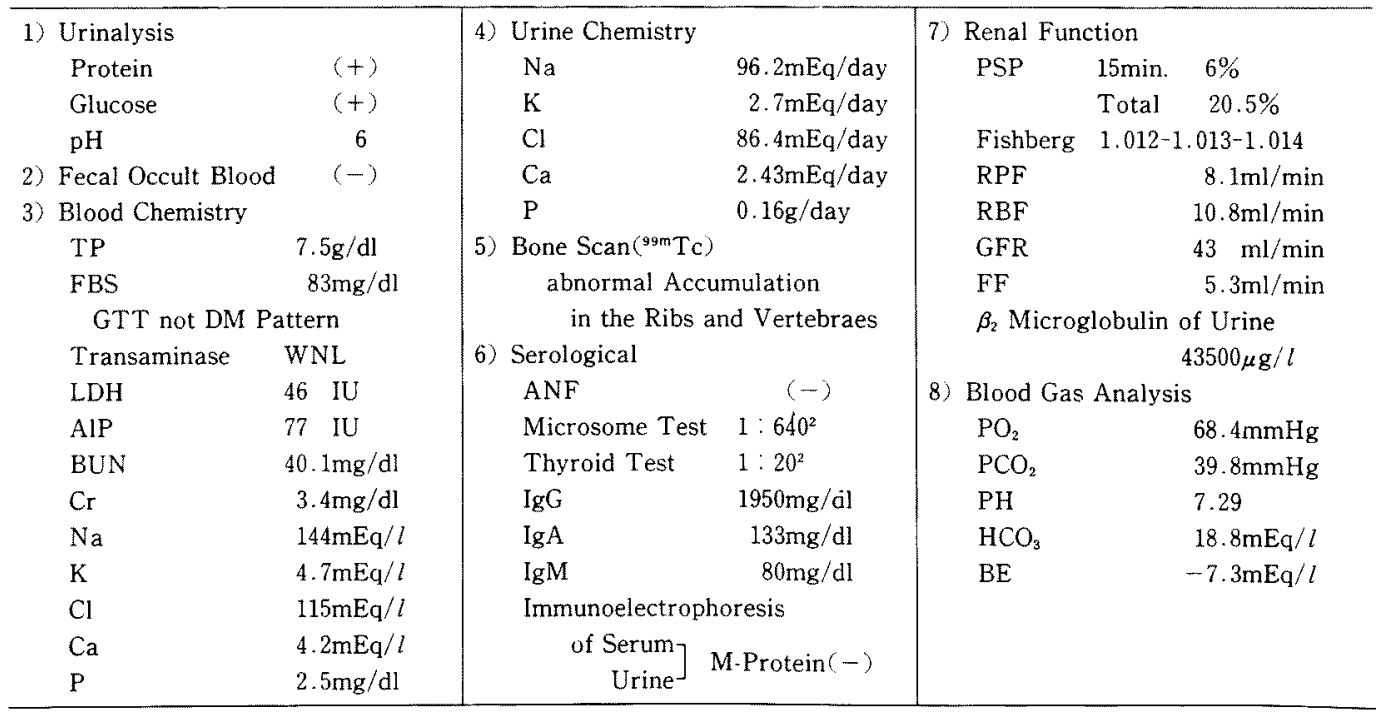


入院時現症： 意識清, 脈拍 $64 /$ 分整. 血生 $130 /$ 60 , 浮腫 $(-)$, 眼䀫結膜 顊血 $(+)$, 龟背 $(+)$, 心尖部に駆出性雑音 $(+)$, Levine 1 度. 腹部 肝 脾腫 $($ 一) 。左下腹部に圧痛 $(+)$.

入院時検查所見：上部，下部消化管の検索で は特に異常所見を認めす，便潜血も陰性で㸷血の 原因として消化管出血は否定された。著明な代謝 性アシドーシスとともに，血清Cl高值，血清Pの低 值が認められた(表 1). $\mathrm{NH}_{4} \mathrm{Cl}$ 負荷試験を施行し たところ（図1），正常では5.8以下に低下する尿 中 $\mathrm{pH}$ が, 本症例では6.8以下に低下せず, 遠位尿細 管障害の存在が考学られた。重曹負荷試験は投与 後数日で浮腫が著明となり中止を余儀なくされた が，PSP排泄試験は15分值 6\%，合計で20.5\%之 著明に低下しており，尿中 $\beta_{2}$ microglobulinの著 增と併和せて近位尿細管障害も存在すると考之ら れた。腎性糖承，尿中P高值に加之，ion exchange chromatographyによる尿中アミノ酸分析では (図 2 ), glycine, alanine, tyrosine, PAIBA, leucine, isoleueine, citnilline, hydroxyproline, arginineなどの多種つミ，酸值が高値を示した。 高令のため骨生検は施行しなかつたが，骨X線像
では偽骨折は明らかでないものの，骨萎縮像が著 明であつた。上上の成績より本症例は尿細管性ア ンドーシスを伴うFC症候群上診断された。

血液学的成績：表 2 は入院後 5 力月を経て, 鉄㶡, 輸血の影響がなくなつた時点の血液学的諸 成績である。小球性, 低色素性筫血を認めたが, 血清鉄は注ほ正常で, 赤血球の形態に著明な变形 を認めた，骨䯣穿刺液塗沫標本では小型赤芽球の 過形成が認められたが，巨赤芽球様变化なく， PAS陽性赤芽球もなかつた。鉄芽球出現率は增加 L, Baumgartner-Stäubliら"の方法によるsideroblast scoreは182と著明な高值を示したが，環状 鉄芽球は認められなかつた。染色体は正常, erythrokineticsでは, 赤血球半寿命の短縮はなかつた が, 赤血球鉄利用率, 赤血球鉄回転の低下など, 無効造血の存在を示す成績が得られた。.

高久, 青木らの方法 (2)で測定した赤芽球SALA合 成酵素活性, 顆粒球チトクローム活性は明らかに 低下していたが， $\delta$ ALA脱水素酵素は正常だつた (表 3 ). 赤血球ホルフィリン体のらちcoproporphyrinが増加しており, $\mathrm{HbA}_{2}$ の増加も認められ た. 血中ビタミン $\mathrm{V}_{6}$ 值 (表 4) は正常で, 念のた

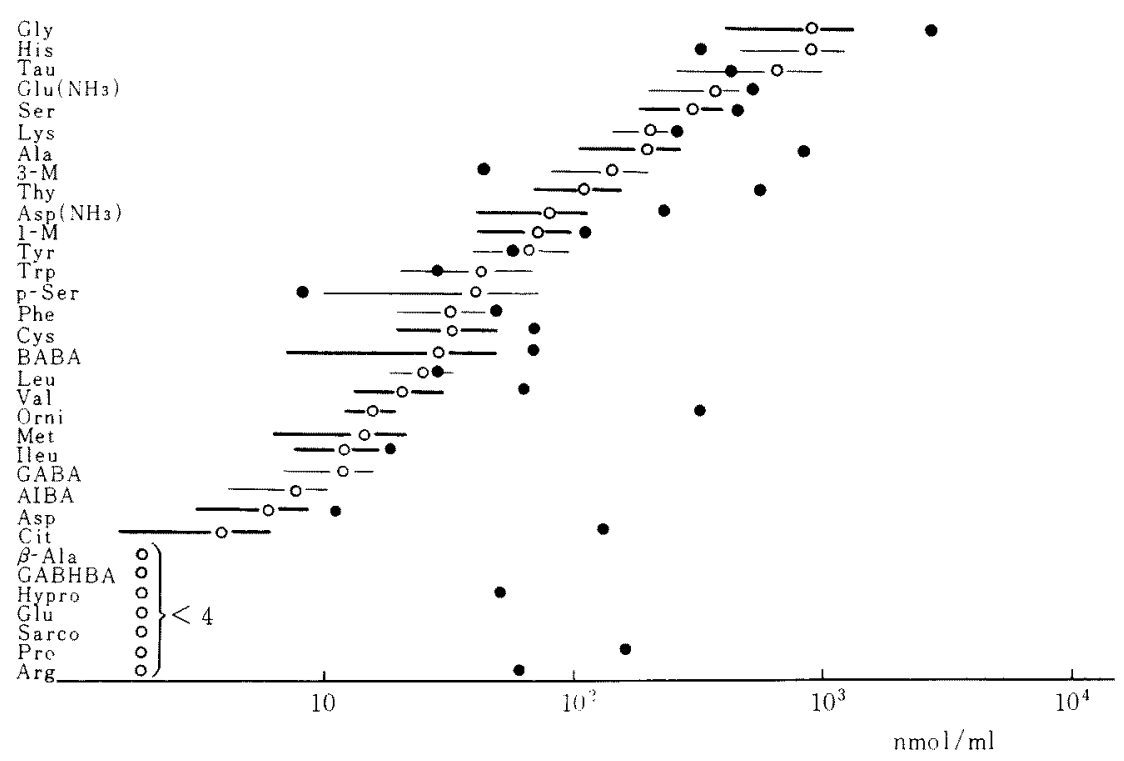

园 2. Amino acid analysis of urine $(-0-$ control, 0 mean, $\bullet$ patient $)$. 
表 2. Hematological findings I

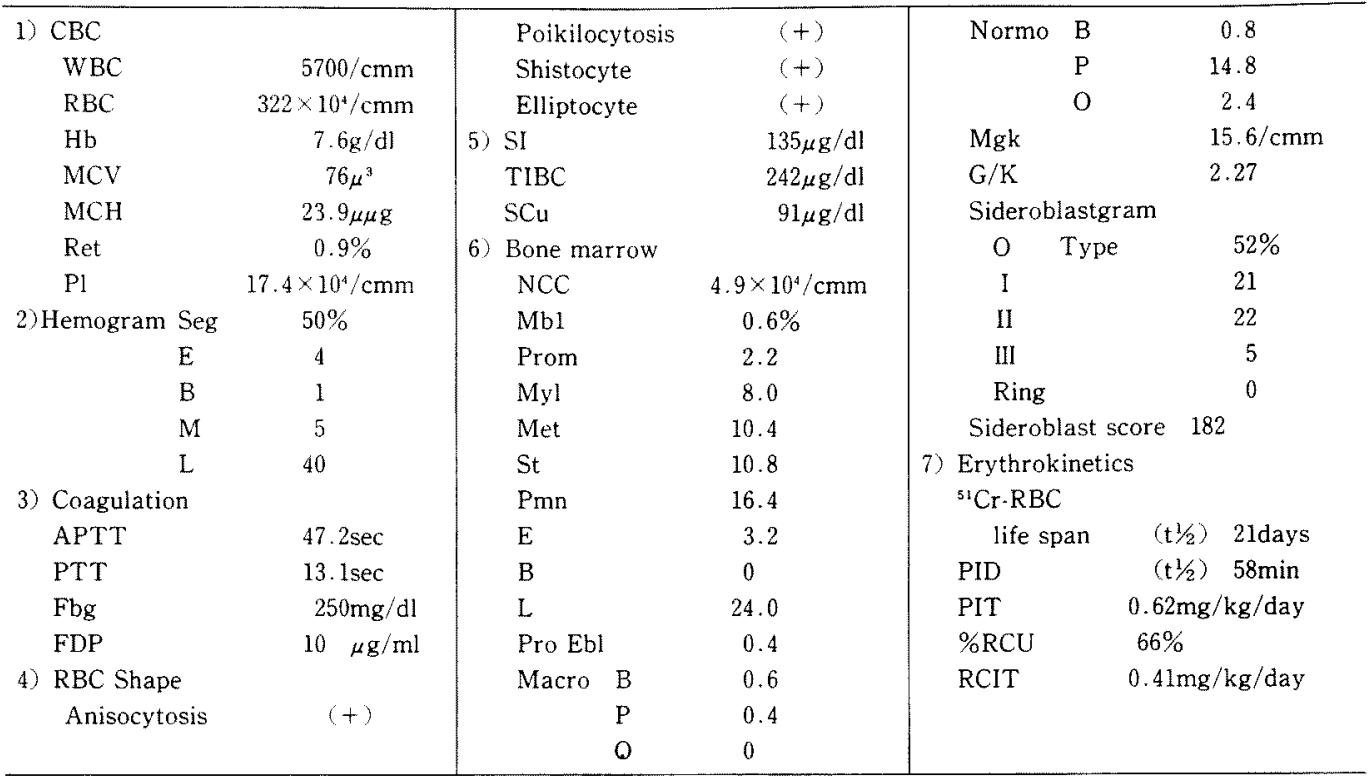

めpyridoxal phosphateの大量連日投与を試みた が応はなからた。

内分泌学的成績(表 4) マイクロゾームテス ト，サイロイドテストは高值を示したが，甲状腺 機能は正常。活性型ビタミンDの著明な低下を認 めまたPTHは2.00ng $/ \mathrm{ml}$ と高值を示し，二次性 副甲状腺機能元進症と診断された。

経過1976年 4 月上り死亡まで，途中血液学 的検索のため中断した約 4 力月索除いては連日 $1.25(\mathrm{OH})_{2} \mathrm{D}_{3} 0.15 \mathrm{mcg}$ 投与した結果, 投与後 2 週間後頃から腰痛の消失，腎性糖尿，低りン血 症は改善, $\mathrm{HbA}_{2}$ 值は正常化し,アミノ酸尿の程度 も軽減した。著明な赤血球の変形も一時ほ活正常 化し，一方代謝性アシドーシスも， $\mathrm{HCO}_{3}^{-} 21.9$ $\mathrm{mEq} / l, \mathrm{BE}-1.8$ 采で改善した。

経過中，尿検查を施行すると，汪上んどの場合 細菌录を呈し，時に米のとぎ汁様で，発熱子認め られた。それに対し抗生物質を投与寸ると，アシ ドーシスが増悪したため，入退院を繰り返した。 1979年頃より進行性の圓血あり，頻回の輸血を要 したが, anabolic steroidの大量投与により貧血の 進行は一時停止した。
1980年 8 月頃より下肢, 手背, 顔面に浮腫が出 現，呼吸困難も認められ，らつ血性心不全之診断， 利尿剂, 食塩制限などで一時改善したものの, 1981 年 4 月再びうつ血性心不全が悪化，DICを合併し て1981年 5 月死亡。

主要病理所見：腎は左右と $50 \mathrm{~g}$ と著明倭 樎していた。 nephrocarcinosis(一)。両腎動脈に は動脈硬化性狭窄が約 $90 \%$ に認められた。繰り返 し生じた慢性采球体腎炎の終末像としての萎縮腎 とは断定できないが，急性腎孟腎炎が認められて おり、この影響が遠位尿細管周囲扣よび管腔内に， リンバ球様細胞, 形質細胞の軽度の侵潤としてで て打り，慢性腎孟腎炎の腎萎縮への関与は大であ ると考えられた。組織学的には中小細動脈硬化像 によるnephronの荒廃に加克，間質の collagenが 增生, 泉細管の昖張, 上皮脱落を認め, 近位, 遠 位尿細管上も一体になつて区別がつきにくく，部 分的にthyroidationを諗めた（困 3 )。骨は骨粗鬆 症の変化なかに, Harver's canalの比較的軽度な 払張に加之て，骨実質の非再生的萎縮像あり，い くつかのosteoid seamの形成が認められる。以上 より osteoblast, osteoclastの動員はないが, 
表 3. Hematological findings II

\begin{tabular}{|c|c|c|}
\hline \multicolumn{3}{|l|}{ 1) Enzyme Activities } \\
\hline \multicolumn{3}{|c|}{ Erythroblast $\delta$ ALA Activity } \\
\hline \multicolumn{2}{|c|}{$\left(23-38 \mathrm{U} / 10^{8} \mathrm{EBL}\right)$} & 10.2 \\
\hline \multicolumn{3}{|c|}{ Matured Granulocyte Protease Activities } \\
\hline$\left(5000-9000 \mathrm{U} / 10^{8} \mathrm{ce}\right.$ & & 4926 \\
\hline \multicolumn{3}{|c|}{ Cytochrome Oxydase Activities } \\
\hline \multicolumn{3}{|c|}{ Mature Granulocyte $\left(1.0-2.5 \mathrm{sec}^{1} / 10^{8}\right.$ cells/crrette $)$} \\
\hline \multirow{2}{*}{\multicolumn{2}{|c|}{ Lymphocyte $\left(1.0-3.5 \mathrm{sec}^{1} / 10^{8}\right.$ cells/crrette) }} & 0.3 \\
\hline & & 1.2 \\
\hline \multicolumn{3}{|c|}{ Cytrate Synthetase Activities } \\
\hline \multicolumn{2}{|c|}{ Mature Granulocyte $\left(30-50 \mathrm{U} / 10^{8}\right.$ cells $)$} & 43 \\
\hline \multicolumn{2}{|c|}{ Lymphocyte $\left(30-50 \mathrm{U} / 10^{8}\right.$ cells $)$} & 28 \\
\hline \multicolumn{3}{|c|}{$\triangle$ ALA Dehydrogenase Activities } \\
\hline \multicolumn{2}{|c|}{$(0.92 \pm 0.162 \mu \mathrm{molPPG} / \mathrm{mlRBC} / 60 \mathrm{~min})$} & 0.91 \\
\hline \multicolumn{3}{|c|}{ 2) Porphyrin } \\
\hline \multicolumn{2}{|c|}{ RBC Uroporphyrin(0-trace) } & 0 -trace \\
\hline \multicolumn{2}{|c|}{ Coproporphyrin $(0-3.5 \mu \mathrm{g} / \mathrm{dlRBC})$} & 65.47 \\
\hline \multicolumn{2}{|c|}{ Protoporphyrin $(25-50 \mu \mathrm{g} / \mathrm{dlRBC})$} & 45.6 \\
\hline \multicolumn{2}{|c|}{ Urine uroporphyrin $(4.40 \mu \mathrm{g} / l)$} & 3.24 \\
\hline \multicolumn{2}{|c|}{ Coproporphyrin $(40.200 \mu \mathrm{g} / l)$} & 2.74 \\
\hline \multicolumn{2}{|c|}{ Protoporphyrin $(0$-trace $)$} & 0 -trace \\
\hline \multicolumn{3}{|c|}{ 3) ATPase of RBC Membrane } \\
\hline \multicolumn{3}{|c|}{ Na-K-ATPase $(252-744 \mu$ molePi released/g protein $)$} \\
\hline & 678 \\
\hline Mg-ATPase(1026-1168 & " & 1,385 \\
\hline \multicolumn{2}{|c|}{ 4) $\mathrm{Hb} \mathrm{F}$ (less than $2.0 \%) 7.19,1978$} & 0.06 \\
\hline \multirow{3}{*}{$\mathrm{Hb} \mathrm{A}_{2}(2.2-3.7 \%)$} & 2.17. 1980 & 1.6 \\
\hline & $7.19,1978$ & 7.04 \\
\hline & $2.17,1980$ & 3.7 \\
\hline
\end{tabular}

表 4. Hormone and Vitamin levels in the serum

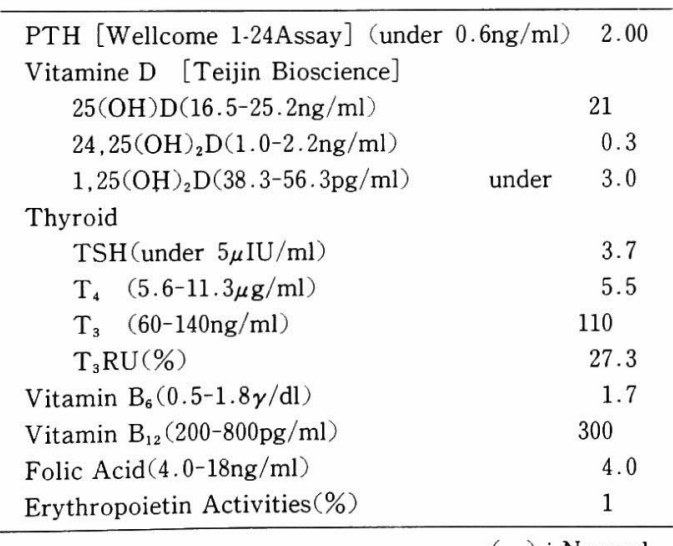

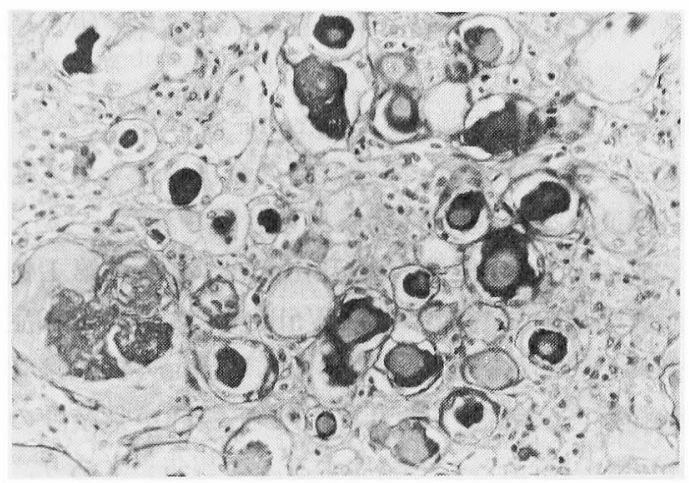

図 3.Distal tubuli の部分的拡張と thyroidation （腎 $\times 25 ）$

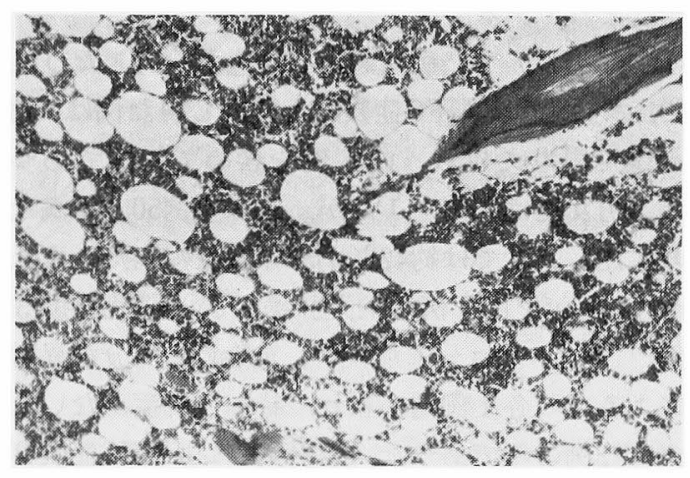

図 4. Osteoporomalacia, osteoid seam \& erythroid hyperplasia（椎体骨 $\times 10 ）$

osteoporo-malaticな変化と考光られた(図 4 )。骨 䯣は赤色䯣で赤芽球の過形成を認めた。

\section{III. 考 案}

FC症候群には，先天性か後天性か，一次性か二 次性か，幼年型か成人型かなどのいくつかの分類 法があり，統一は末だされていない、先天性のも のとしては, cystinosis, Wilson病, Lowe症候群, hereditary fructose intolerance, tyrosinemia, ビタミン D依存性くる病, galactosemiaなどの報 告があるが、これらは汪とんど幼年から少年期に 発症するもので，本症例は高令にいたるまで症状 の発現をみておらず，明らかにこれらとは異なる と思わ机る。後天性のものとしては, 薬物として 変性tetracycline, 6MP, metyl-5-chrome, 重金属 として鉛, カドミウム, 水銀などが知られている 
が，本症例はこれらの薬物投与症はなく，重金属 污染地域に居住したといらこともないまた悪性 腫煌, 多発性骨髄腫, Sjögren症候群, アミロイ ドーンス，ネフローゼ㱏候群の合併はなく，本症 例は成人型本態性FC症候群と診断された。

成人型FC症候群はMilkman ${ }^{6}$ とよつて第 1 例 が報告され，1957年にはWallisら多とよつて18症 例がまとめられている。しかしWallisの例には骨 鹃道腫が多数混じつており，FC症候群が骨䯣腫の latent formとして発症するとの報告闺あり， FC症候群と骨䯙腫との関係を論じた報告は少な くない,一方骨戟腫を除いた成人型FC症候群の報 告はま机である。

本邦に扣いて発症時および経過を検討したら光 で，本態性成人型FC症候群と診断し得た例は，調 べ得た限りでは我々の症例を含めて23例であつ た。男女比は約 $1 ： 1$ だが，男は全例50才末満な

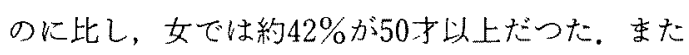
myopathyを伴う例 5 例, 肝癌などの悪性腫瘍 3 例11) 13), ネフローゼ症候群, 重金属, 内分泌異常 によるもの各 1 例認められ, 特に合併症がないも のは12例のみであつた。腫場除去により FC症候群 が軽快したとの報告 ${ }^{(4)}$ あすり，“本態性”の用い方 に混乱があるとい党よう。我々の症例では，かな りの長期にわたつて慢性腎监腎炎があつたと思わ れ, 剖検にても著明な間質性腎炎像を呈しており, このことが本例に認められたdistal RTAの原因 と考えられた。一方重曹負荷試験は施行できなか つたが，その他の検查成績より，近位尿細管障害 の存在も明らかで，これも間質性腎炎によるnephronの荒廃によると思われた，注目されること は，他の60才以上の高令女性FC症候群例 ${ }^{11} に も ，$ 間質性变化を強く認めた点である。老年者に叔い て繰り返す承路感染症扎上びそれに随伴する間質 性腎炎様変化は珍しくないが、FC症候群発生は極 めて希であり，直接その成因を論ずることは難し いが，本症例を含めた高令者 2 例は，長期にわた る慢性系球体腎炎と，広範から著明な間質性腎炎 を特徴としており，FC症候群の病態を考えると き，興味ある所見と考光られた。
尚本症例に認められた，抗生物質投与時アシ ドーシスが増悪する現象の機序は不明である。た だペニシリン系をはじめ多くの抗生物質が腎尿細 管より排泄されることが知られており，尿細管障 害のため排泄されず，血中濃度が高くなつた諸抗 生物質が，さらに尿細管を障害した可能性は考慮 してよい上考党られた。

本症例のも5一つの特徵忖, 小球性, 低色素性 貧血である、鉄欠乏はなく，骨䯣穿刺液塗沫標本 鉄染色にても鉄芽球は多数認められたが，環状鉄 芽球は認められなかつた。しかし鉄回転では無効 造血があり，赤芽球 $\delta$ ALA合成醉素も著明に低下 していた。これはHeilmeyerら ${ }^{15)}$ 鉄芽球性貧血 の診断規準の条件にほとんど合致するものの，必 要条件としての環状鉄芽球は認められず，このた め鉄芽球性貧血とは崄断し点ない

Rhoads, Barker'16)によつて提唱されたrefractory anemiaは，骨䯣はnormoblasticまたは macronormoblastic erythroid hyperplasiaで, 骨 䯣や組織には赤芽球, 貯蔵鉄が増加し, 鉄代謝で は無効造血を呈する治療低抗性の賽血々定義さ れ，その成因は不明である。種々の赤血球醏素異 常, $\mathrm{HbF}, \mathrm{Hb} \mathrm{A}$ 増加をはじめとするへモグロビ

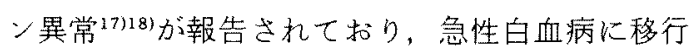
寸る例を認められ，FAB グループ ${ }^{19}$ myelodysplastic syndromeの一型としている. 以上より 本症例は，鉄芽球性貧血に近いところに位置する refractory anemiaと考充られた。

本例では $\mathrm{HbA}_{2}$ 值が増加していたことから， $\beta$ thalassemia 考慮し，二人の子供を検查したが， 異常は認められなかつた。 $\mathrm{HbA}_{2}$ が経過中正常化 したことも考完あおせ、これはrefractory anemia に伴つた変化と考光られた。

\section{IV. 結 語}

以上refractory anemiaを合併した成人型FC症 候群について報告し，文献的考察を加之た。両者 とも腫瘍性疾患との関係が注目されて就り，この 点さらに娭討を要すると思われた。

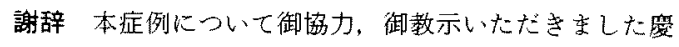
応大学薬化研 星野患夫, 自治医科大学 青木洋祐, 関東 
週信病院体液研 中尾急，国立公衆衛生院栄羡生化近藤 雅雄，東京大学第一内科夰家利承，同老人科折茂綮の 各先生に深謝します。

\section{文献}

1) Lignac GOE: Über Störung des Cystinstoffwechsels bei Kinden. Dtsch Arch klin Med 145: 139, 1924.

2) Fanconi G : Die nicht diabetischen Glykosur. ien und Hyperglykämien des älteren kindes. Jahrb Kinderheilk 133: 256, 1931.

3) Fanconi G: Der frühinfantile nephrotisch glycosurische Zwergwuchs mit hypophosphatämischer Rachinitis. Jahrb Kinderheilk $147: 299,1936$.

4) De Toni G: Remarks on the relationship between renal rickets (renal dwarfism) and renal diabetes. Acta Paediat 16: 479, 1933.

5) Debré $R$, et al : Rachitisme tardif coexistant avec une néphrite chronique et une glycosurie. Arch Méd Enf 37 : 597, 1934

6) Milkman LA: Pseudofractures (hunger osteopathy, late rickets, osteomalacia). Report of a case. Amer J Roentgenol 24:29, 1930.

7) Baumgartner-Stäubli $R$ and Beck EA: Sideroblast score: A sensitive indicater of iron deficiency and hypoproliferative anemia. Acta Haematol $57: 24,1977$.

8) Takaku F, et al: $\Delta$-aminolevulic acid synthetase activity of a human bone marrow erythroid cells in various haematological disorders. Tohoku J Exp Med 107 : 217, 1972
9) Wallis LA, et al: The adult Fanconi syndrome. Amer J Med 22: 13, 1957.

10) Maldonado JE, et al: Fanconi syndrome in adults: A manifestation of latent form of myeloma. Amer J Med 58: 354, 1975.

11）大原弘道，他：成人型Fanconi症侯群の一剖検例, 代謝 $10 ： 154 １ 973$.

12）水島哲也，他：悪性腫滨を伴つたadult Fanconi syndromeの 2 例。骨代謝 $13 ： 155 ， 1980$.

13）阿保七三郎, 他：Fanconi症候群を伴つた胸部食 道癌の症例。胸部外科 $33: 397,1980$.

14) 福本泰明, 他 : Tumor induced osteomalaciaの 病因分析. II. Fanconi店候群類似の腎尿細管障害 について。因泌誌 $55 ： 447,1979$.

15) Heilmyer L: Disturbance in heme synthesis : Special considerations of the sideroblastic anemia and erythropoietic porphyrias. Thomas, Springfield III, 1966, p103.

16) Road CP, et al: Refractory anemia; analysis of 100 cases. J Amer Med Ass 110: 794, 1938.

17) Boguslawski-Jaworst $J$ and Dobryszycka $W$ : Hemoglobinopatite w Bialaczkach u dzieu. Pol Tyg Lek $16: 281,1961$.

18) Rosa J, et al: Evidence for various types of synthesis of human alpha chains of haemog. lobin in acquired haematological disorders. Nature [New Biol] 233: 111, 1971.

19) Bennett JM, et al: Proposals for the classification of the myelodysplastic syndromes. Brit J Haematol 51 : 189, 1982. 